Article

\title{
Disposition of Lightning Activity Due to Pollution Load during Dissimilar Seasons as Observed from Satellite and Ground-Based Data
}

\author{
Anirban Middey * and Pankaj B. Kaware \\ Air Pollution Control Division, National Environmental Engineering Research Institute, Nehru Marg, \\ Nagpur 440020, India; pankajkaware.2009@rediffmail.com \\ * Correspondence: a_middey@neeri.res.in; Tel.: +91-0712-224-988-588 (ext. 441)
}

Academic Editor: Christina Anagnostopoulou

Received: 8 December 2015; Accepted: 3 May 2016; Published: 16 May 2016

\begin{abstract}
The precise role of air pollution on the climate and local weather has been an issue for quite a long time. Among the diverse issues, the effects of air pollution on lightning are of recent interest. Exploration over several years (2004 to 2011) has been made over Gangetic West Bengal of India using lightning flash data from TRMM-LIS (Tropical Rainfall Measuring Mission-Lightning Imaging Sensor), atmospheric pollutants, and rainfall data during pre-monsoon (April and May) and monsoon (June, July, August and September) seasons. Near-surface pollutants such as $\mathrm{PM}_{10}$ and $\mathrm{SO}_{2}$ have a good positive association with aerosol optical depth (AOD) for both the pre-monsoon and monsoon months. High atmospheric aerosol loading correlates well with pre-monsoon and monsoon lightning flashes. However, rainfall has a dissimilar effect on lightning flashes. Flash count is positively associated with pre-monsoon rainfall $(r=0.64)$, but the reverse relation $(r=-0.4)$ is observed for monsoon rainfall. Apart from meteorological factors, wet deposition of atmospheric pollutant may be considered a crucial factor for decreased lightning flash count in monsoon. The variation in the monthly average tropospheric column amount of $\mathrm{NO}_{2}$, from the Tropospheric Emission Monitoring Internet Service (TEMIS), is synchronic with average lightning flash rate. It has a good linear association with flash count for both pre-monsoon and monsoon seasons. The effect of lightning on tropospheric $\mathrm{NO}_{2}$ production is evident from the monthly average variation in $\mathrm{NO}_{2}$ on lightning and non-lightning days.
\end{abstract}

Keywords: lightning; pollution; aerosols; pre-monsoon; monsoon

\section{Introduction}

Common components of urban air pollution such as particulate matter (PM), sulfur oxides, and nitrogen oxides play crucial roles in weather modification at local as well as global levels. In spite of substantial research [1-7] on the effect of urban atmospheres on regional and global weather, a precise understanding of the very topic is yet to develop. A large number of studies about the consequence of an urban area on the local weather activities has been carried out in different geographical locations around the globe [8-12]. However, the majority of these studies has attributed the impact of air pollution on the urban heat island circulation. Near-surface pollutants such as $\mathrm{PM}_{2.5}$ and $\mathrm{PM}_{10}[13,14]$ from natural and anthropogenic sources contribute to aerosol [15] formation and thus influence various physical phenomena such as cloud formation, rainfall, lightning, etc. [16]. Engel-Cox et al. [17] showed a good correlation between MODIS aerosol optical depth (AOD) and $\mathrm{PM}_{2.5}$ in the Eastern US, but those are apparently more elusive in the Western US due to a combination of the differences between ground-based and column average datasets, regression artifacts, variability of terrain, etc. The physical relationship between lightning activity and precipitation [18-20] regarding the effect 
of air pollution are well established. Pollution over the cities can elevate the cloud condensation nuclei $(\mathrm{CCN})$ concentration, which in turn might produce changes in the microphysical processes taking place inside the clouds. Lal and Pawar [21] showed a large contrast between pre-monsoon and monsoon lightning as well as their correlations with rainfall. Studies have shown that the influence of thermo-dynamical properties as well as an increase in aerosol concentration can affect lightning activity in a region $[22,23]$.

Over the past few decades, enormous industrial activity, urbanization, and other anthropogenic actions have been a regular issue for Gangetic West Bengal, as it has become a necessary for the livelihood of the growing population. At the same time, it has brought some alarming effects [24].

The purpose of the present study is to explore the effect of surface pollutants such as $\mathrm{PM}_{10}$ and $\mathrm{SO}_{2}$ as well as atmospheric aerosols and rainfall on pre-monsoon and monsoon lightning activity over Gangetic West Bengal. Additionally, lightning's contribution on in tropospheric $\mathrm{NO}_{2}$ column amount is surveyed over the same region.

\section{Site Description}

The location of the study is Gangetic West Bengal (Figure 1) (latitude: $21.5^{\circ} \mathrm{N}$ to $24.5^{\circ} \mathrm{N}$; longitude: $86.0^{\circ} \mathrm{E}$ to $89.0^{\circ} \mathrm{E}$ ), which is on the eastern end of the Indo-Gangetic Plain and a major part of the Ganges Delta. During pre-monsoon months (April-May), the site experiences severe local storms [25,26], associated with strong winds and rain that last for short durations. Large-scale and mesoscale interactions significantly influence the severity of such convective storms. Daily average temperature varies from $30{ }^{\circ} \mathrm{C}$ to $35{ }^{\circ} \mathrm{C}$ in April and May. Isolated to heavy pulse rainfall (0 to $150 \mathrm{~mm}$ ) occurs due to local severe storm activity [27]. Sometimes, pre-monsoon tropical cyclones form over the Bay of Bengal and approach the site with severe rainfall and damaging winds. In the summer monsoon months (June-September), the area receives considerable rainfall. The normal onset date of Indian summer monsoon over Gangetic West Bengal is 10 June. Monthly average rainfall during summer monsoon varies from $250 \mathrm{~mm}$ to $350 \mathrm{~mm}$.

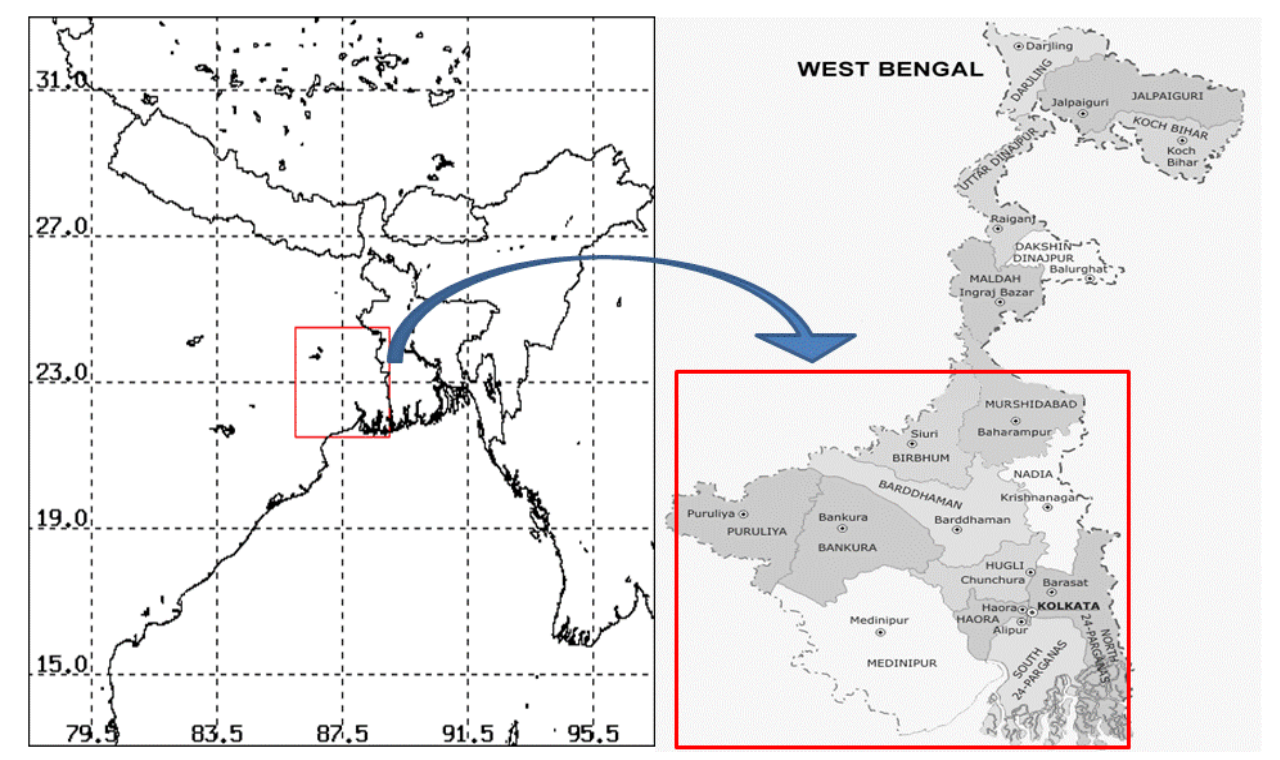

Figure 1. Area of interest (red rectangle), Gangetic West Bengal of India (latitude: $21.5^{\circ} \mathrm{N}$ to $24.5^{\circ} \mathrm{N}$; longitude: $86.0^{\circ} \mathrm{E}$ to $89.0^{\circ} \mathrm{E}$ ). Source: LIS (Lightning Imaging Sensor) and Maps of India.

As per the records of Department of Municipal Affairs, the Government of West Bengal, and data from Census 2011 released by the State's Directorate of Census Operations, there has been a rapid growth in urban population in West Bengal since 1951, while the latest Census (2011) data reveals that the decadal growth rate of urban population in West Bengal exceeds $(0.73 \%)$ the national 
average. The number of villages has come down from 40,782 in 2001 to 40,203 in 2011. While the rural population has grown by only $7.73 \%$ since 2001 , the urban population has jumped up by $29.90 \%$ in 10 years, with each of the 19 districts showing a higher population growth in urban areas. Analysis of monthly rainfall data obtained from the India Meteorological Department of the Government of India over the last two decades shows that there has been a $14.8 \%$ decrease in average pre-monsoon rainfall amount between decades 1991-2000 and 2001-2010, where a 6.4\% decrement occurred in the average monsoon rainfall. However, some station selective studies show variable results of the urban effect. Mitra et al. [28] showed that the rate of change of urban land cover has increased by 50\% compared to the period prior to India's independence in 1947 over Kolkata district, and pre-monsoon rainfall has increased, whereas Lal and Pawar [29] pointed out the decreasing trend in accumulated rainfall in Kolkata due to the urban heat effect.
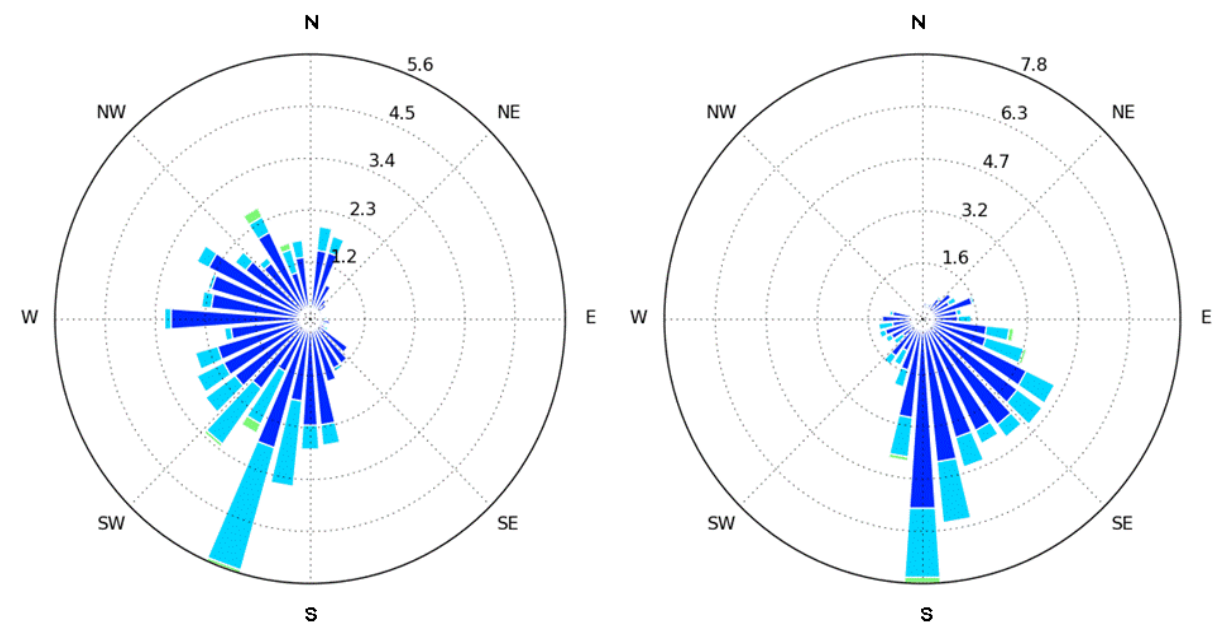

Pre-monsoon Wind speed in $\mathrm{m} / \mathrm{s}$

Monsoon

(a)
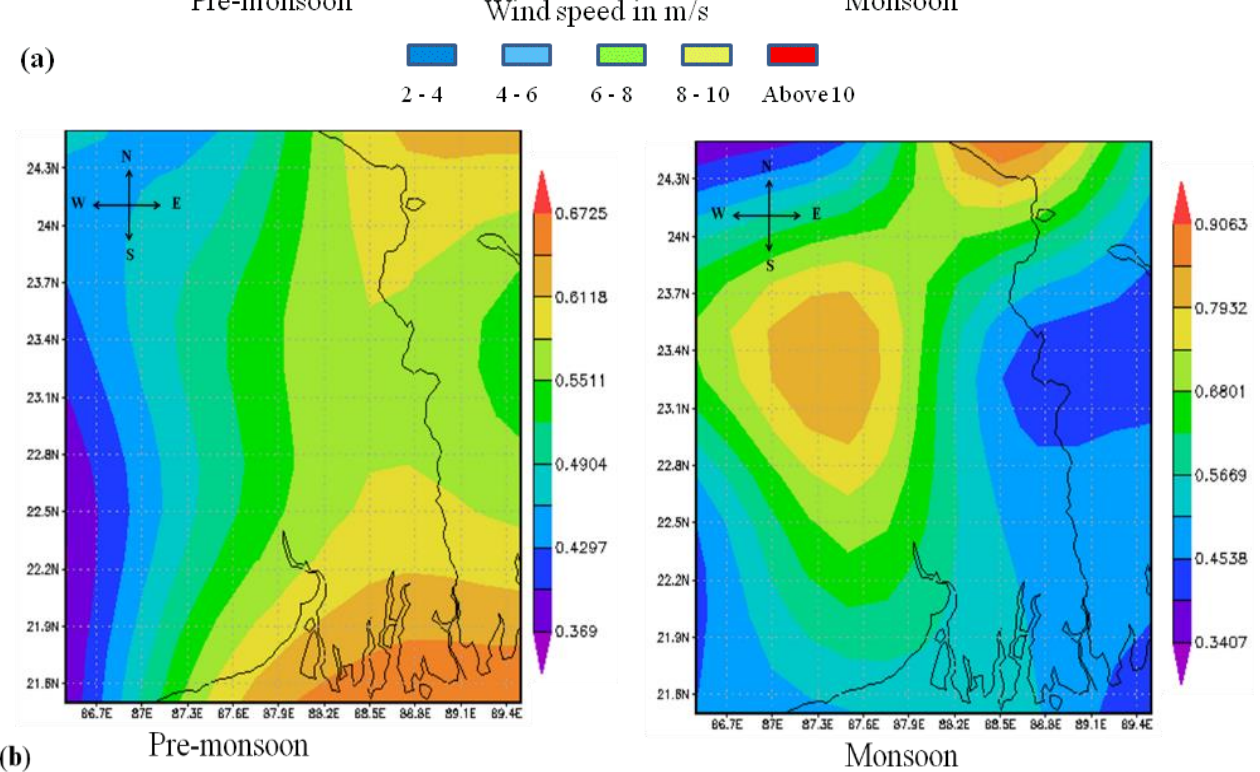

Figure 2. Wind pattern and AOD over Gangetic West Bengal during pre-monsoon and post monsoon seasons. (a) Wind rose diagrams showing dissimilarity in the distribution of wind speed and direction for a station (Dumdum, Kolkata: latitude: $22.62^{\circ} \mathrm{N}$; longitude: $88.42^{\circ} \mathrm{E}$ ); (b) AOD contours during two seasons.

Surface wind pattern over the study area is assessed using wind rose diagrams (Figure 2a) for a particular station (Kolkata: latitude: $22.62^{\circ} \mathrm{N}$; longitude: $88.42^{\circ} \mathrm{E}$ ) during pre-monsoon and monsoon seasons. Upwind and downwind patterns have noticeable dissimilarity between the two seasons. 
During pre-monsoon, predominant wind blows towards NNE, E, and SSE directions (downwind), whereas monsoon season dominates the wind towards N, NNW, and NW (downwind) directions. Contours of AOD (Figure $2 b$ ) over the region show increased concentration of aerosol downwind of the location for both seasons.

\section{Materials and Methods}

Pollution data were collected by West Bengal Pollution Control Board (WBPCB) of India, which includes the concentration of particulate matter $10\left(\mathrm{PM}_{10}\right)$ and sulfur dioxide $\left(\mathrm{SO}_{2}\right)$ over 13 districts (North and South 24 Parganas, Midapur East and West, Bankura, Burdwan, Purulia, Kolkata, Howrah, Hoogly, Murshidabad, Nadia, and Birbhum) of Gangetic West Bengal. Every district has its town and municipal areas which play a crucial part in ambient air quality values. Daily values of $\mathrm{PM}_{10}$ and $\mathrm{SO}_{2}$, as taken by WBPCB, were collected from 2004 to 2011 for further analysis. The lightning data (daily) is collected from the LIS (Lightning Imaging Sensor) database for the same time span (i.e., 2004-2011). The LIS is a Tropical Rainfall Measuring Mission (TRMM) satellite-based instrument and detects cloud and ground lightning activities in the troposphere [30]. Both intra-cloud and cloud-to-ground (CG) lightning flash rate are taken for the present study. The TRMM satellite circled the Earth at an altitude of $350 \mathrm{~km}$ (The TRMM satellite was boosted from an altitude of 350-402 km in August 2001 to extend its mission life) with an inclination of $35^{\circ}$. The LIS satellite takes approximately 49 days to return to its original position relative to the Sun and the Earth, though the manual recommends using a 100-day window. The LIS and OTD (optical transient detector) sensors monitor the 777.4-nm atomic oxygen multiplet, detecting pulses of illumination (produced by lightning) above background levels. LIS has a much smaller field of view, but has a higher detection efficiency than an OTD [31]. Lightning flash times and locations are recorded with an approximately 5-km resolution from LIS. However, the limits of LIS data is one cannot distinguish between inter-cloud (IC) and CG lightning activity. It provides the total (IC + CG) lighting count. Daily AOD values are collected from MODIS (aqua/terra) satellite products (Level 3 daily data for $1^{\circ} \times 1^{\circ}$ grid, collection 5.1). Monthly accumulated surface rainfall (in $\mathrm{mm}$ ) data are collected from TRMM Online Visualization and Analysis System (TOVAS) over the selected region. Regional tropospheric $\mathrm{NO}_{2}$ column data are obtained from the Tropospheric Emission Monitoring Internet Service (TEMIS), which provides data for the Ozone Monitoring Instrument (OMI) on board NASA's Aura satellite [32]. The tropospheric $\mathrm{NO}_{2}$ column values are also collected on a monthly basis. To obtain the value of the lifting condensation level (LCL) over an urban metropolis (Kolkata) on the selected area, radiosonde observations (launched twice daily at 00 UTC and 12 UTC) of vertical atmosphere from the India Meteorological Department (IMD) are made and analyzed. All required data (air pollution, rainfall, AOD and flashes) are collected daily during 2004-2011 over the region and then aggregated and averaged out for each month (seasonally) in order to find correlations. For pre-monsoon months (April and May), every year has 61 days, and for eight years (2004-2011) there are $8 \times 61=488$ days of data. Similarly, for monsoon months (June, July, August, and September) there are 122 days in a year, and for eight years $976(122 \times 8)$ numbers of data points are available for each parameters. All monthly data are then averaged out to make a seasonal representation.

\section{Data Limitations}

Ground-monitored particulate matter and $\mathrm{SO}_{2}$ values are taken from West Bengal Pollution Control Board's data archive, which represents average values of pollution parameters over a particular district. Urban and rural activities in terms of the above-mentioned pollution parameters are averaged out to produce a single representative value. However, that does not affect the results and analysis of the present work as the accumulative impact of all districts on lightning activity for two dissimilar seasons is examined. As mentioned above, TRMM-based LIS lightning data are considered in the present study. LIS has a 5-km instantaneous field of view (IFOV) with a detection efficiency greater than $90 \%$ for all events. The statistical distribution of the number of optical pulses in a flash was found to be exponential in character, with about 12 optical pulses per flash as a mean . About $90 \%$ of the 
lightning in this study produced peak radiant energy densities of $4.7 \mu \mathrm{J} \cdot \mathrm{m}^{-2} \cdot \mathrm{sr}^{-1}$ or greater (the unit represents an amount of energy in $\mu \mathrm{J}$ per square meter of area per steradian solid angle). Hence, in the design of the LIS, this energy value has been assumed as the appropriate threshold requirement for LIS to achieve $90 \%$ detection efficiency. The false alarm rate of $10 \%$ may associate with the present data analysis; however, qualitative estimations pertaining to the urban effect on total lightning activity will not be affected. The limitation of the MODIS satellite product is that the AOD can be obtained from clear sky conditions.

\section{Results and Discussion}

All required data (air pollution, rainfall, AOD, and flashes) were collected daily during 2004-2011 over the region and then aggregated and averaged out for each month (seasonally) in order to find correlations.

Average values of surface pollutions parameters $\left(\mathrm{PM}_{10}, \mathrm{SO}_{2}\right)$ from the selected region show a reasonable correlation (Figure 3) with atmospheric AOD. However, there are discrepancies in the results obtained from pre-monsoon cases with monsoon. The correlation coefficient $(r)$ between $\mathrm{PM}_{10}$ and AOD were found to be 0.84 and 0.63 for pre-monsoon and monsoon periods, respectively. A lower amount of correlation during monsoon was expected due to atmospheric washout by precipitation. On the contrary, the correlation coefficient $(r)$ between $\mathrm{SO}_{2}$ and AOD during monsoon was observed to be slightly higher (0.77) than that of the pre-monsoon period (0.71). It is obvious that sulfate particles are usually more active in cloud droplet formation than $\mathrm{PM}_{10}$. Very recently, Neely III et al. [33] identified a seasonally occurring aerosol layer over Asia, which is sustained and dominated by anthropogenic $\mathrm{SO}_{2}$ emissions. Anthropogenic aerosols are the main contributor to the atmospheric $\mathrm{AOD}$, and its variation over the selected urban region is quite synchronized with lightning flash activity. Recently, Yuan et al. [34] studied lightning activity over the West Pacific Ocean east of the Philippines using LIS lightning data and AOD from MODIS, and found that an $\sim 60 \%$ increase in aerosol loading leads to a more than $150 \%$ increase in lightning flashes. The reason behind this is the modification of cloud microphysics by aerosol. More aerosol loading reduces the size of cloud ice particle, and cloud icing is delayed in lower temperatures and mixed-phase clouds; activity increases, and, as a result, charge separation increases, and chances of lightning flashes also increase. Figure 4 represents the variation in AOD along with lightning flash count over the years and their corresponding scatter plots for pre-monsoon and monsoon seasons. The degree of association, as observed from $r$ values, during pre-monsoon months are higher $(r=0.81)$ than monsoon months $(r=0.74)$. The science of the aerosol effect on lightning flash is well grounded by much of the literature $[35,36]$. Increase in the aerosol concentration cuts down the droplet size, decreasing the warm rain coalescence process and raising the cloud water that reaches the mixed-phase region. This results in an increased amount of liquid water in the cloud, consequently modifying the microphysical processes of icing and cloud electrification [37]. A comparatively low correlation coefficient value $(r=0.74)$ between AOD and lightning flash count in monsoon months can be explained according to Rosenfeld et al. [38]. The effect of aerosol in producing rainfall is observed as a result of their radiative and CCN activities. The CCN concentration drops considerably during the active monsoon period, and, because of large moisture contents, the cloud base height remains low during the monsoon with compared to the pre-monsoon.

Rainfall received over Gangetic West Bengal during pre-monsoon months are mainly due to thunderstorm activities, whereas, in the monsoon months, the large amount of rainfall received over the Gangetic plain is due to active monsoon circulation. Figure 5 shows accumulated seasonal average surface rainfall during pre-monsoon and monsoon seasons. Naturally, the average rainfall during monsoon months is much higher than pre-monsoon months, but the relation with lightning flash count shows discrepancies. Urban air pollution can suppress rainfall because the pollution particles prevent cloud water from condensing into raindrops [39]. There is always a smaller amount of rainfall observed downwind than upwind (see Figure 5a,b). However, in the case of lightning activity, an opposite trend is observed and justified. Lightning flash count over the total selected region of Gangetic West Bengal is observed to increase with increasing aerosol load over the region (see Figure 5b). This is also evident 
from the recent study by Yang and Li [40], where they found that an accumulation of aerosols over moist plain land invigorates thundercloud activity. The heat island effect seems to have more impact on rainfall than lightning over the study area.
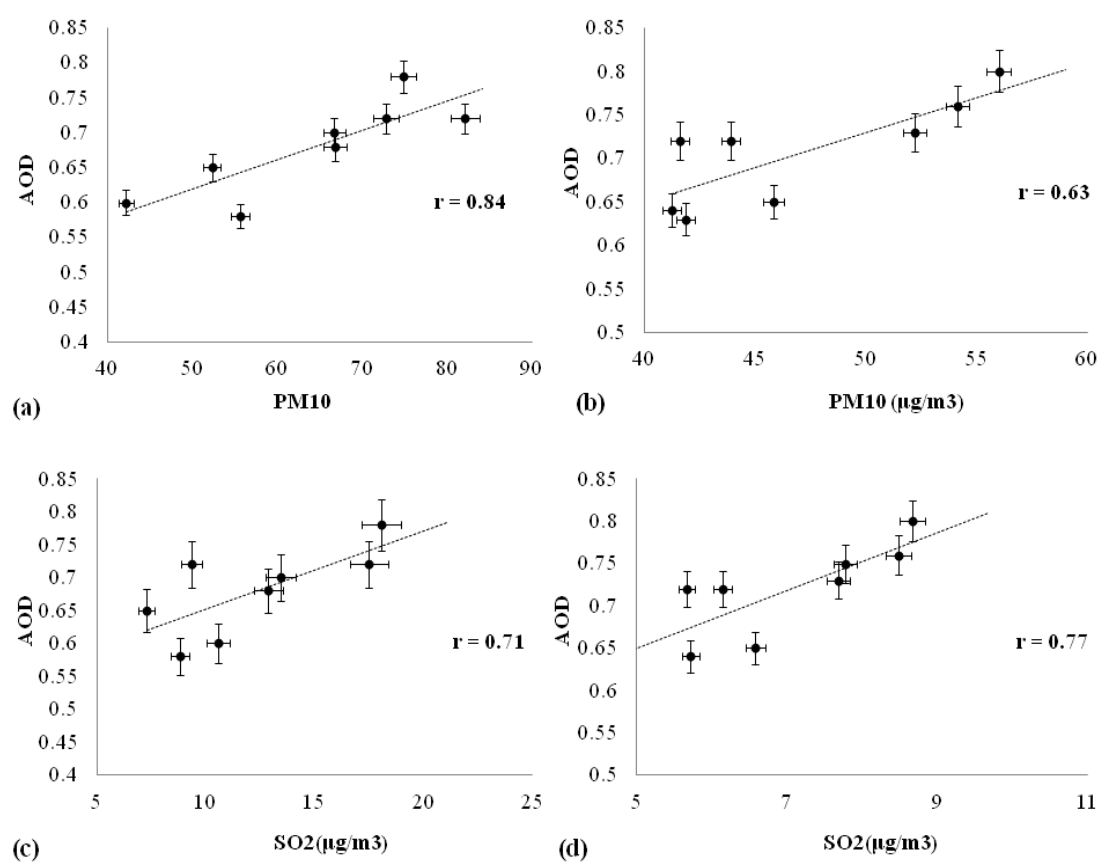

Figure 3. Scatter diagram of monthly PM10 and AOD over 8 years for (a) pre-monsoon (April-May) and (b) monsoon (June-September) and that of monthly SO2 and AOD for (c) pre-monsoon (April-May) and (d) monsoon (June-September). Crosshairs represent first standard deviation of the parameters.
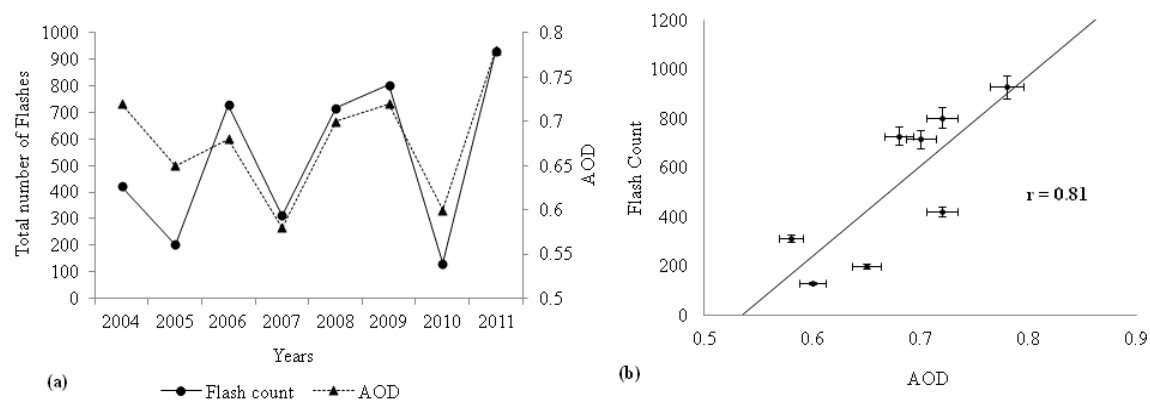

(b)
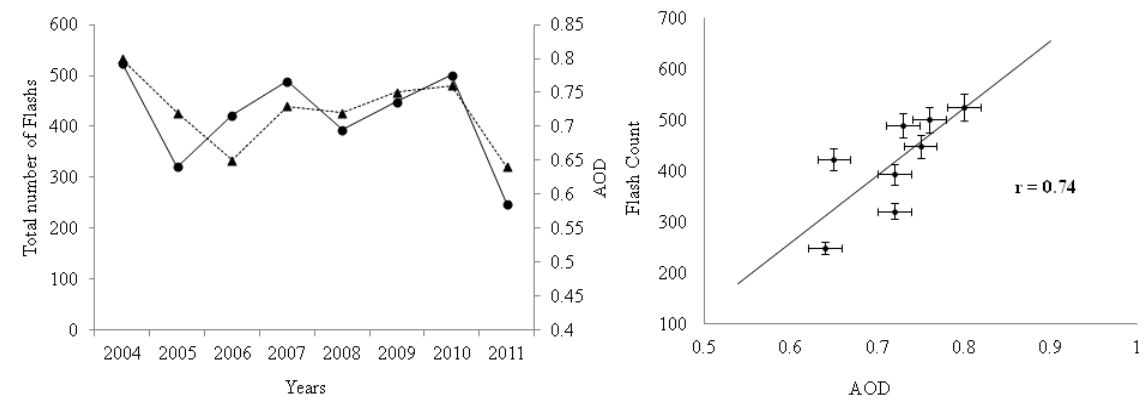

(c)

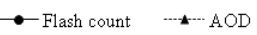

(d)

Figure 4. Comparison of flash count with AOD. (a) Variation in total number of flashes along with AOD over the years (2004-2011) and (b) their scatter plot during pre-monsoon months; (c) Monsoon period variation in total flashes and AOD and (d) their scatter plot. Crosshairs represent first standard deviation of the parameters. 

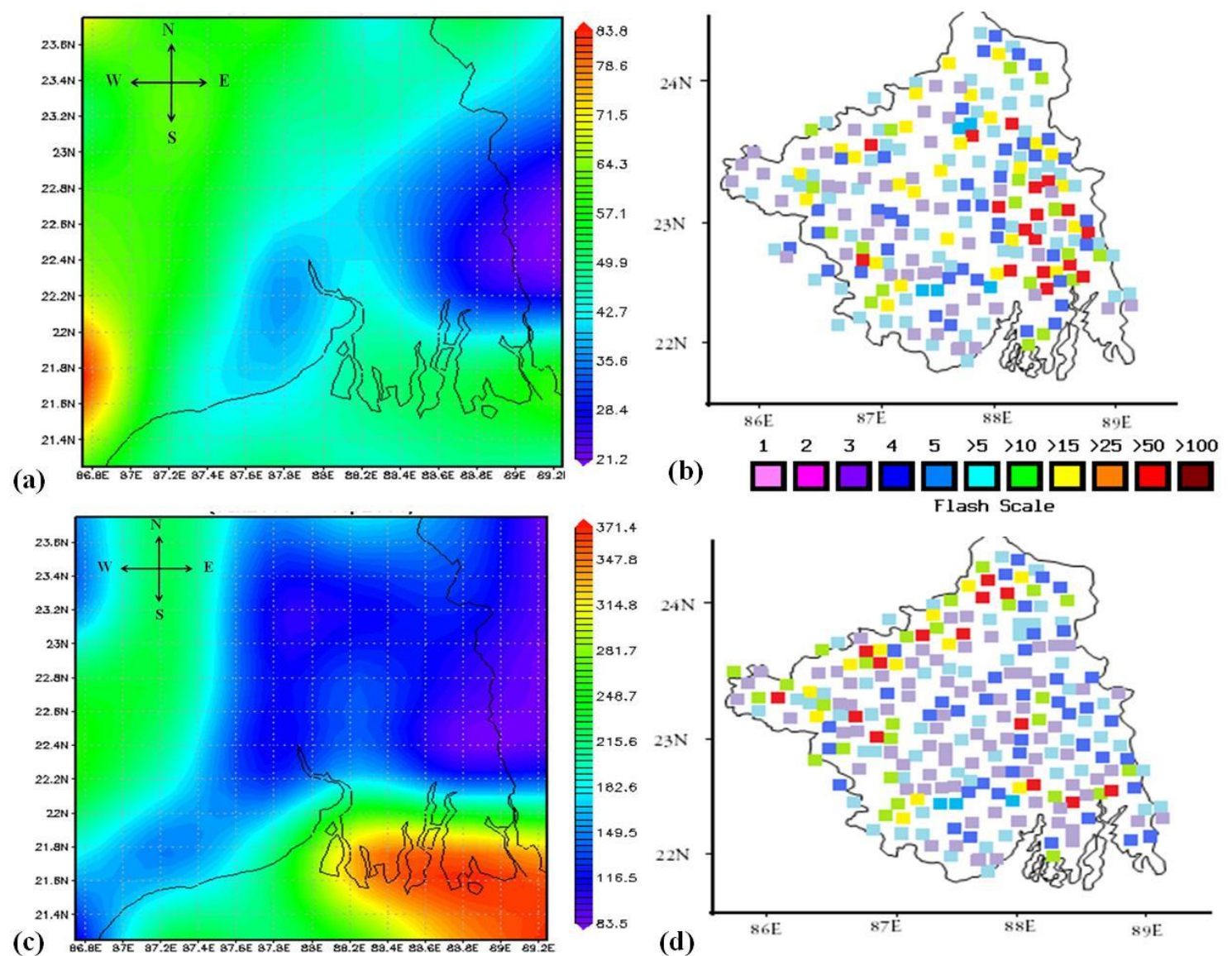

Figure 5. Accumulated surface average rainfalls $(\mathrm{mm})$ and average lightning flash count during pre-monsoon season ((a) and (b) respectively) and during monsoon seasons ((c) and (d) respectively) over Gangetic West Bengal.

Monthly average rainfall and the corresponding average flash count are plotted against the months (per-monsoon and monsoon) in Figure 6a, which clearly shows two dissimilar trends. Lightning flash count increases as rainfall increases during pre-monsoon months, while flash count decreases as rainfall during monsoon month increases. Analysis of the cloud base was done using the height of the LCL (Figure $6 \mathrm{~b}$ ) over a meteorological station, Kolkata $\left(22.65^{\circ} \mathrm{N}, 88.45^{\circ} \mathrm{E}\right)$, in Gangetic West Bengal [41]. Pre-monsoon months have much higher LCL than do monsoon months. As the station moved closer to the sea, an adequate amount of moisture incurred during active monsoon, which resulted in a very low cloud base (around $500 \mathrm{~m}$ ). Thus, the combined effect of less CCN concentration and low LCL height bring out the dissimilar patterns in the relation between rainfall and lightning flash count during pre-monsoon and monsoon season. The scatter plot (Figure $6 c, d$ ) of flash count and rainfall during pre-monsoon and monsoon seasons depicts a clearer picture about the dissimilar trends. The pre-monsoon rainfall is positively well associated with lightning flash count, as evident from the correlation coefficient ( $\mathrm{r}$ ) value of 0.64 , while the monthly monsoon rainfall (in $\mathrm{mm}$ ) is negatively associated with lightning flash count $(r=-0.4)$. This can be explained by the fact that aerosol concentration falls considerably during the active monsoon period, the cloud base height remains low, and there is huge amount of moisture content during the monsoon when compared to pre-monsoon. Huge concentrations of human-made aerosols have been reported to both decrease and increase rainfall as a result of their relative and $\mathrm{CCN}$ activities. Tropical clouds with small CCN concentrations rain out too rapidly to form into stable clouds, whereas highly polluted clouds, due to the radioactive effect, evaporate their water before precipitation can occur. Anthropogenic aerosol loading over the Indian Ocean varies with the cyclic nature of the Indian Monsoon. From June to October, the wet monsoon 
brings clean air into the region from the Southern Hemisphere. Conversely, the dry monsoon brings polluted air from the Indian subcontinent and Southeast Asia from November through April [42]. Pre-monsoon season possesses more cumulonimbus (CB) clouds, but their formation is less frequent, while clouds in monsoon season (low, middle, and high) with widespread cloud cover are observed due to monsoonal circulation.
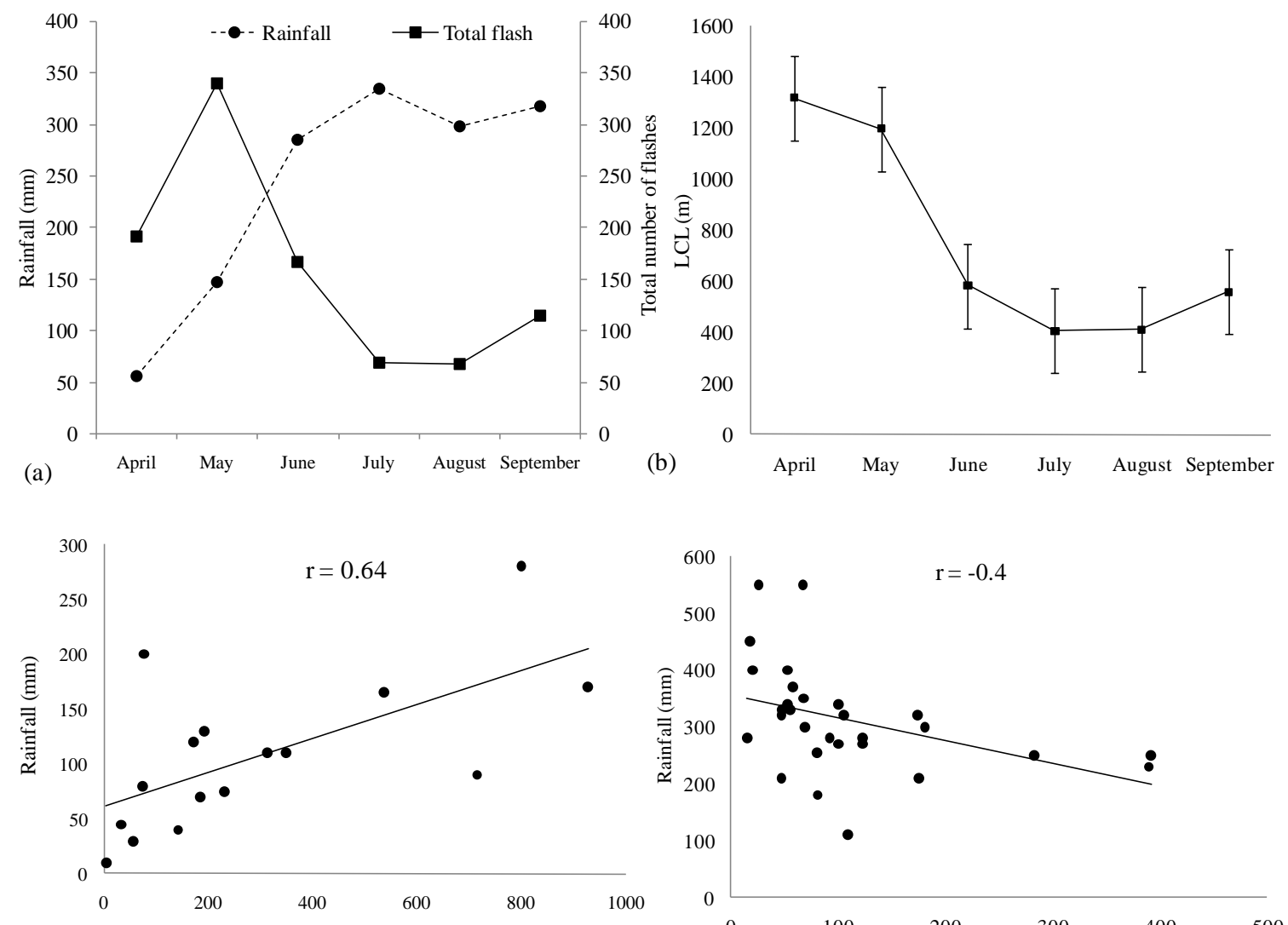

(c)

Lightning Flash count

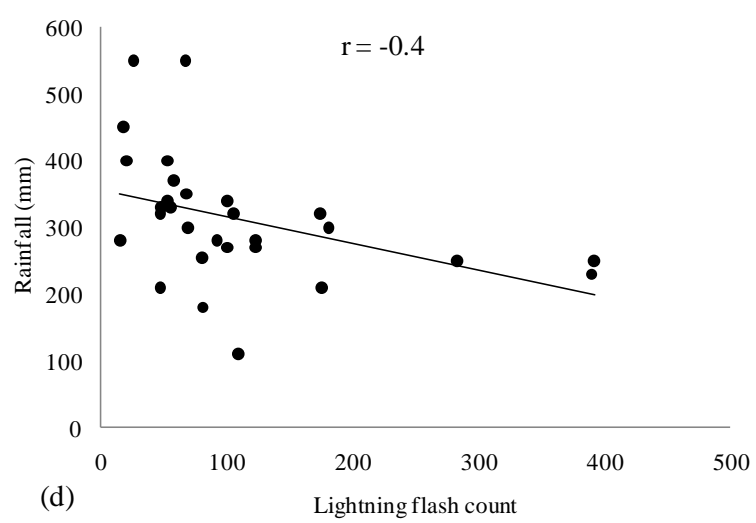

Figure 6. Comparison of rainfall and lightning flash count in view of LCL. (a) Variation of monthly average rainfall (mm) and average number of lightning flashes. (b) Lifting condensation level (LCL) over a meteorological station (Kolkata) in Gangetic West Bengal over the months (April to September) and Scatter diagram of lightning flash count and rainfall for (c) pre-monsoon (April-May) and (d) monsoon (June-September) periods from 2004 to 2011. Error bars represent first standard deviation of the parameter.

On the other hand, atmospheric lightning discharge is one major natural source of $\mathrm{NO}_{2}$ production in the troposphere. Due to extreme heat generated during lightning flashes, atmospheric nitrogen and oxygen react with each other to form nitric oxide $(\mathrm{NO})$ and nitrogen dioxide $\left(\mathrm{NO}_{2}\right)$. Apart from a natural source (lightning), $\mathrm{NO}_{2}$ can be generated in the troposphere by urban contributions such as vehicle combustion, industrial emissions, etc. [43,44]. The troposphere column amount of $\mathrm{NO}_{2}$ (in molecules $/ \mathrm{cm}^{2}$ ) is taken form lightning days in pre-monsoon and monsoon months. It was found that the amount of tropospheric $\mathrm{NO}_{2}$ is concurrent (Figure 7a) with lightning flash values for both seasons (pre-monsoon and monsoon). The effect of lightning on $\mathrm{NO}_{2}$ production has become more prominent when a lightning and non-lightning day's $\mathrm{NO}_{2}$ are compared on a monthly basis. Figure $7 \mathrm{~b}$ depicts the variation in the amount of tropospheric $\mathrm{NO}_{2}$ over Gangetic West Bengal for lightning and non-lightning days during various months. It shows a significantly increased value of $\mathrm{NO}_{2}$ during lightning days of the respective months than the non-lightning days of the same month. The scatter plots (Figure 8) with the tropospheric column amount of $\mathrm{NO}_{2}$ and lightning flash count 
for both pre-monsoon and monsoon months show positive correlations ( 0.63 and 0.52 respectively). The correlation coefficient values reflect that $\mathrm{NO}_{2}$ production in pre-monsoon months is more sensitive to corresponding lightning flash count than the monsoon months. This may be simply due to the higher lightning flash count in the pre-monsoon months compared to the monsoon months. By increasing production of $\mathrm{NO}_{2}$ in the tropospheric regions, lightning flashes contributes to surface $\mathrm{O}_{3}$ generation, which has already been identified and established by many researchers.

$$
\begin{gathered}
\mathrm{NO}_{2}+h v \rightarrow \mathrm{NO}+\mathrm{O} \\
\mathrm{O}+\mathrm{O}_{2} \rightarrow \mathrm{O}_{3}+\mathrm{M}
\end{gathered}
$$

$\mathrm{O}_{3}$ in the lower troposphere acts as a pollutant and has been identified to be a potent respiratory hazard that is difficult to control. Apart from the contribution towards various chemical species in the atmosphere, lightning itself is a great hazard and has a high socio-economic impact over the selected location. Every year, lightning causes agricultural loss, property loss, and death in Gangetic West Bengal, which necessitates all-encompassing research on lightning activity.
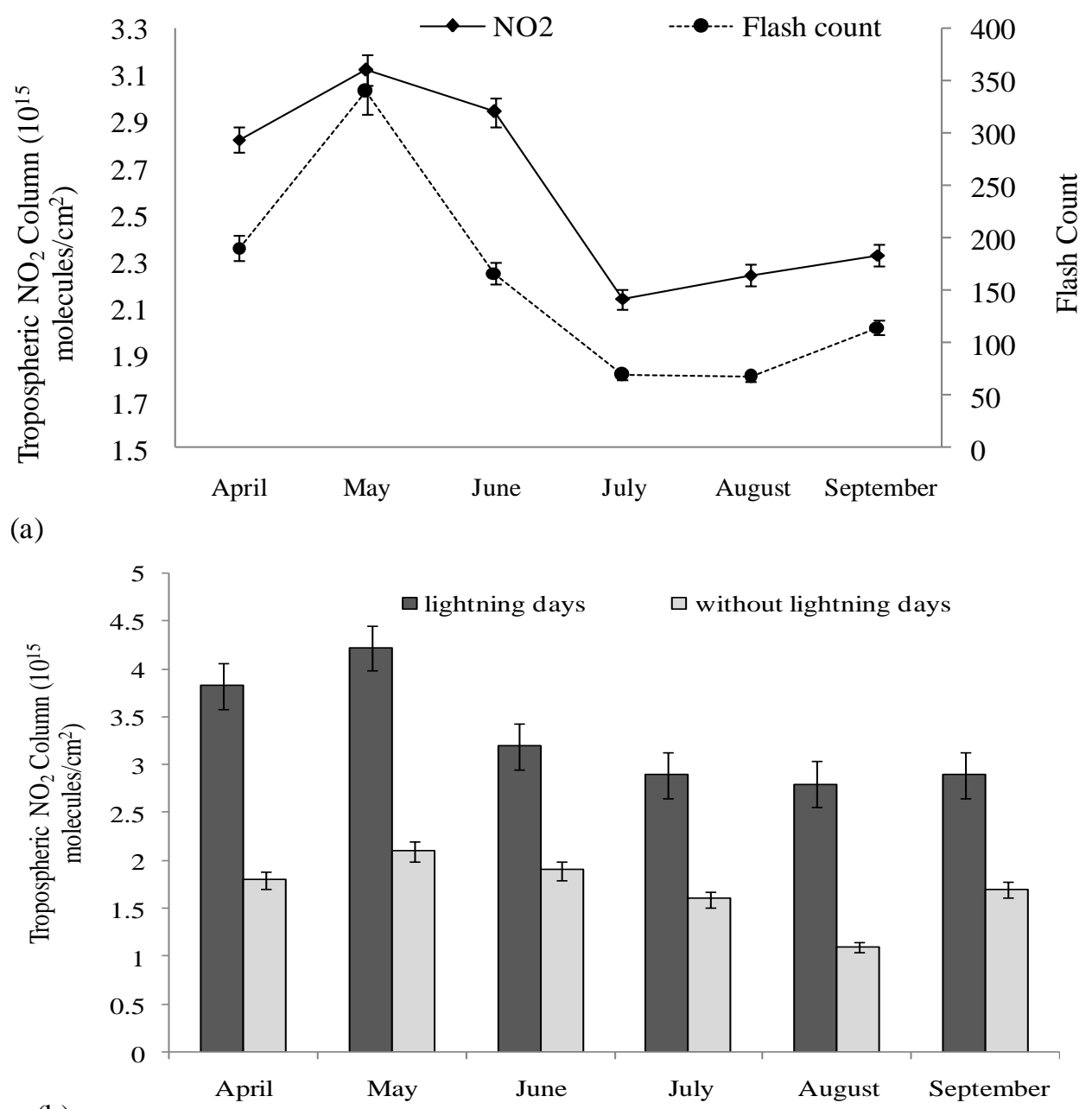

(b)

Figure 7. Relation between tropospheric NO2 and lighting activity (a) Variations of monthly average tropospheric $\mathrm{NO}_{2}$ column amount and lightning flash count from 2004 to 2011 and (b) average tropospheric $\mathrm{NO}_{2}$ column amount of lightning and non-lightning days from 2005 to 2011. Error bars represent first standard deviation of the parameter. 

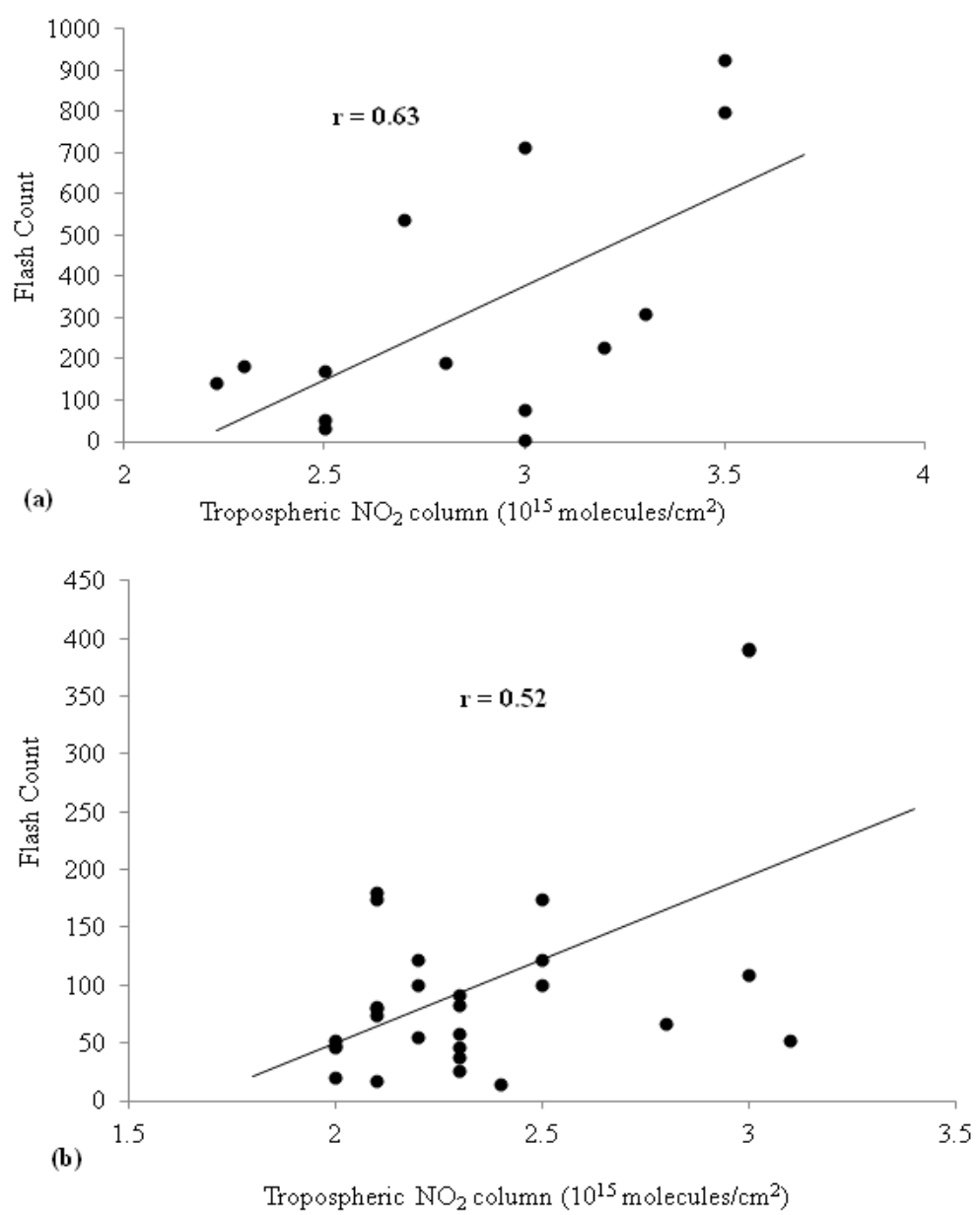

Figure 8. Scatter plot of tropospheric $\mathrm{NO}_{2}$ column amount $v$ s. lightning flash count for (a) pre-monsoon (April-May) and (b) monsoon (June-September) months from 2005 to 2011.

\section{Conclusions}

Pollution, lightning, and rainfall triune over the plain of Gangetic West Bengal show very different responses for pre-monsoon and monsoon seasons. Surface pollutants such as $\mathrm{PM}_{10}$ and $\mathrm{SO}_{2}$ have a direct relation with atmospheric aerosol loading (as evident from correlations with AOD). Due to the geographical position, the area has good access to adequate moisture from the neighboring sea (Bay of Bengal). As aerosol loading increases (through urban pollution) in the atmosphere, more polluted clouds with mixed phases (ice crystal and water) stimulate the potential of lightning discharge. An optimum balance between cloud water and $\mathrm{CCN}$ concentration through surface pollution favors lightning flash during pre-monsoon months. However, during monsoon months, a large amount of atmospheric aerosol gets washed out by rainfall; consequently, flash count decreases. Nevertheless, atmospheric pollution and lightning flash activity are positively associated with each other in both seasons. As the surface pollution induces lightning activity over the selected area, lightning flash also produces a huge amount of $\mathrm{NO}_{2}$ in the troposphere. Lightning as a natural source of tropospheric $\mathrm{NO}_{2}$ is well identified and compared with the effect of other sources on non-lightning days.

Acknowledgments: The authors acknowledge TRMM Online Visualization and Analysis System (TOVAS) and Lightning Imaging Sensor (LIS), West Bengal Pollution Control Board (WBPCB), Tropospheric Emission Monitoring Internet Service (TEMIS), MODIS Online Visualization and Analysis System (MOVAS) for making the required data available for the research. Thanks are due to the anonymous reviewers for constructive comments and suggestions which helped to improve the clarity of the article. 
Author Contributions: Anirban Middey conceptualized and designed the study and collected and analyzed the data; Pankaj B. Kaware contributed in data analysis and helped write the paper.

Conflicts of Interest: The authors declare no conflict of interest.

\section{References}

1. Braham, R.R.; Semonin, R.G.; Auer, A.H.; Changnon, S.A., Jr.; Hales, J.M. Summary of urban effects on clouds and rain, in Metromex: A review and summary. Meteorol. Monogr. Am. Meteorol. Soc. 1981, 40, 141-169.

2. Balling, R.C.; Idso, S.B. Historical temperature trends in the US and the effect of urban population growth. J. Geophys. Res. 1989, 84, 3359-3363. [CrossRef]

3. Lyons, W.A.; Nemson, T.E.; Williams, E.R.; Cramer, J.A.; Turner, T.R. Enhanced positive cloud-to-ground lightning in thunderstorms ingesting smoke from fires. Science 1998, 282, 77-80. [CrossRef] [PubMed]

4. Westcott, N.E. Summertime cloud-to-ground lightning activity around major Midwestern urban areas. J. Appl. Meteorol. 1995, 34, 1633-1642. [CrossRef]

5. Murray, N.D.; Orville, R.E.; Huffines, G.R. Effect of pollution from Central America fires on cloud-to-ground lightning in May 1998. Geophys. Res. Lett. 2000, 27, 2249-2252. [CrossRef]

6. Rosenfeld, D.; Lensky, I.M. Satellite-based insights into precipitation formation processes in continental and maritime convective clouds. Bull. Am. Meteorol. Soc. 1998, 79, 2457-2476. [CrossRef]

7. Naccarato, K.P.; Pinto, O., Jr.; Pinto, I.R.C.A. Evidence of thermal and aerosol effects on the cloud-to-ground lightning density and polarity over large urban areas of South eastern Brazil. Geophys. Res. Lett. 2003, 30, 71-74. [CrossRef]

8. Orville, R.R.; Huffines, G.; Gammon, J.N.; Zhang, R.; Ely, B.; Steiger, S.; Phillips, S.; Allen, S.; Read, W. Enhancement of cloud-to-ground lightning over Houston, Texas. Geophys. Res. Lett. 2001, 28, 2597-2600. [CrossRef]

9. Kim, Y.H.; Baik, J.J. Daily maximum urban heat island intensity in large cities of Korea. Theor. Appl. Climatol. 2004, 79, 151-164. [CrossRef]

10. Fan, H.; Sailor, D.J. Modeling the impacts of anthropogenic heating on the urban climate of Philadelphia: A comparison of implementations in two PBL schemes. Atmos. Environ. 2005, 39, 73-84. [CrossRef]

11. Chen, T.C.; Wang, S.Y.; Yen, M.C. Enhancement of afternoon thunderstorm activity by urbanization in a valley: Taipei. J. Appl. Meteorol. Climatol. 2007, 36, 1324-1340. [CrossRef]

12. Sarrata, C.; Lemonsub, A.; Massona, V.; Guedaliac, D. Impact of urban heat island on regional atmospheric pollution. Atmos. Environ. 2006, 40, 1743-1758. [CrossRef]

13. Kumar, N.; Chu, D.A.; Foster, A. An empirical relationship between $\mathrm{PM}_{2.5}$ and aerosol optical depth in Delhi Metropolitan. Atmos. Environ. 2007, 41, 4492-4503. [CrossRef] [PubMed]

14. Kumar, N.; Allen Chu, D.; Foster, A. Remote sensing of ambient particles in Delhi and its environs: Estimation and validation. Int. J. Remote Sens. 2008, 29, 3383-3405. [CrossRef] [PubMed]

15. Tsai, T.C.; Jeng, Y.J.; Allen Chu, D.; Chen, J.P.; Chang, S.C. Analysis of the relationship between MODIS aerosol optical depth and particulate matter from 2006 to 2008. Atmos. Environ. 2011, 45, 4777-4788. [CrossRef]

16. Han, J.Y.; Baik, J.J.; Lee, H. Urban impacts on precipitation. Asia Pac. J. Atmos. Sci. 2014, 50, 17-30. [CrossRef]

17. Engel-Cox, J.A.; Holloman, C.H.; Coutant, B.W.; Hoff, R.M. Qualitative and quantitative evaluation of MODIS satellite sensor data for regional and urbanscale air quality. Atmos. Environ. 2004, 38, 2495-2509. [CrossRef]

18. Shepherd, J.M. A review of current investigations of urban-induced rainfall and recommendations for the future. Earth Interact. 2005, 9, 1-27. [CrossRef]

19. Soriano, L.R.; Pablo, F. Effect of small urban areas in central Spain on the enhancement of cloud-to-ground lightning activity. Atmos. Environ. 2002, 36, 2809-2816. [CrossRef]

20. Pawar, S.D.; Lal, D.M.; Murugavel, P. Lightning characteristics over central India during Indian summer monsoon. Atmos. Res. 2012, 106, 44-49. [CrossRef]

21. Lal, D.M.; Pawar, S.D. Relationship between rainfall and lightning over central Indian region in monsoon and pre monsoon seasons. Atmos. Res. 2009, 92, 402-410. [CrossRef] 
22. Bell, T.L.; Rosenfeld, D.; Kim, K.M. Weekly cycle of lightning: Evidence of storm invigoration by pollution. Geophys. Res. Lett. 2009, 36. [CrossRef]

23. Bell, T.L.; Rosenfeld, D.; Kim, K.M.; Yoo, J.M.; Lee, M.I.; Hahnen berger, M. Midweek increase in U.S. summer rain and storm heights suggests air pollution invigorates rainstorms. J. Geophys. Res. 2008, 113. [CrossRef]

24. Li, Z.; Niu, F.; Fan, J.; Liu, Y.; Rosenfeld, D.; Ding, Y. Long-term impacts of aerosols on the vertical development of clouds and precipitation. Nat. Geosci. 2011, 4, 888-894. [CrossRef]

25. Yuan, T.; Qie, X. Study on lightning activity and precipitation characteristics before and after the onset of the South China Sea summer monsoon. J. Geophys. Res. 2008, 113, D14. [CrossRef]

26. Liou, Y.A.; Kar, S.K. Study of cloud-to-ground lightning and precipitation and their seasonal and geographical characteristics over Taiwan. Atmos. Res. 2010, 95, 115-122. [CrossRef]

27. Nath, K.D. Nature of urbanization in West Bengal in the POST-independence period. Econ. Aff. 2009, 54, 149-164.

28. Mitra, C.; Shepherd, J.M.; Jordan, T. On the relationship between the premonsoonal rainfall climatology and urban land cover dynamics in Kolkata city, India. Int. J. Climatol. 2012, 32, 1443-1454. [CrossRef]

29. Lal, D.M.; Pawar, S.D. Effect of urbanization on lightning over four metropolitan cities of India. Atmos. Environ. 2011, 45, 191-196. [CrossRef]

30. Cecil, D.J.; Goodman, S.J.; Boccippio, D.J.; Zipser, E.J.; Nesbitt, S.W. Three years of TRMM precipitation features-Part I: Radar, radiometric, and lightning characteristics. Mon. Weather Rev. 2005, 133, 543566. [CrossRef]

31. Boccippio, D.J.; Koshak, W.J.; Blakeslee, R.J. Performance assessment of the Optical Transient Detector and Lightning Imaging Sensor-Part I: Predicted diurnal variability. J. Atmos. Ocean. Technol. 2002, 19, 1318-1332. [CrossRef]

32. Boersma, K.F.; Eskes, H.J.; Veefkind, J.P.; Brinksma, E.J.; van der A, R.J.; Sneep, M.; van den Oord, G.H.J.; Levelt, P.F.; Stammes, P.; Gleason, J.F.; et al. Near-real time retrieval of tropospheric $\mathrm{NO}_{2}$ from OMI. Atmos. Chem. Phys. 2007, 2013-2128.

33. Neely, R.R., III; Yu, P.; Rosenlof, K.H.; Toon, O.B.; Daniel, J.S.; Solomon, S.; Miller, H.L. The contribution of anthropogenic $\mathrm{SO}_{2}$ emissions to the Asian tropopause aerosol layer. J. Geophys. Res. 2014, 119, 1571-1579.

34. Yuan, T.; Remer, L.A.; Pickering, K.E.; Yu, H. Observational evidence of aerosol enhancement of lightning activity and convective invigoration. Geophys. Res. Lett. 2011, 38, L04701. [CrossRef]

35. Rosenfeld, D.; Woodley, W. Pollution and clouds. Phys. World 2001, 14, 33-37. [CrossRef]

36. Williams, E.R.; Boldi, B.; Matlin, A.; Weber, M.; Hodanish, S.; Sharp, D.; Goodman, S.; Raghavan, R.; Buechler, D. The behavior of total lightning activity in severe Florida thunderstorms. Atmos. Res. 1999, 51, 245-265. [CrossRef]

37. Farias, W.R.G.; Pinto, O., Jr.; Naccarato, K.P.; Pinto, I.R.C.A. Anomalous lightning activity over the Metropolitan Region of São Paulo dueto urban effects. Atmos. Res. 2009, 91, 485-490. [CrossRef]

38. Rosenfeld, D.; Lohmann, U.; Raga, G.B.; O’Dowd, C.D.; Kulmala, M.; Fuzzi, S.; Reissell, A.; Andreae, M.O. Flood or drought: How do aerosols affect precipitation? Science 2008, 321. [CrossRef] [PubMed]

39. Givati, A.; Rosenfeld, D. Quantifying precipitation suppression due to air pollution. J. Appl. Meteorol. 2004, 43, 1038-1056. [CrossRef]

40. Yang, X.; Li, Z. Increases in thunderstorm activity and relationships with air pollution in southeast China. J. Geophys. Res. 2014, 119, 1835-1844. [CrossRef]

41. Middey, A.; Chaudhuri, S. The reciprocal relation between lightning and pollution and their impact over Kolkata, India. Environ. Sci. Pollut. Res. 2013, 20, 3133-3139. [CrossRef] [PubMed]

42. Chung, C.E.; Ramanathan, V. Aerosol loading over the Indian Ocean and its possible impact on regional climate. Indian J. Mar. Sci. 2004, 33, 40-55.

43. Corrigan, C.E.; Ramanathan, V.; Schauer, J.J. Impact of monsoon transitions on the physical and optical properties of aerosols. J. Geophys. Res. 2006, 111, D18208. [CrossRef]

44. Kar, S.K.; Liou, Y.A.; Ha, K.J. Characteristics of cloud-to-ground lightning activity over Seoul, South Korea in relation to an urban effect. Ann. Geophys. 2007, 25, 2113-2118. [CrossRef]

(C) 2016 by the authors; licensee MDPI, Basel, Switzerland. This article is an open access article distributed under the terms and conditions of the Creative Commons Attribution (CC-BY) license (http://creativecommons.org/licenses/by/4.0/). 